\title{
Participation is Not Enough: An Argument for Emancipation as a Foundation of Participatory Theorising
}

Contemporary participatory theory remains in a problematic disconnect from political practice. This disconnect is often a source of criticism and leads to accusations of the idealistic nature of participatory theory. In this article, I argue that the reasons for this disconnect lie in the theoretical tools used by participatory theorists. While the theory relies on an assumption of the educational effects of political participation and the possibility of societal transformation, the core concepts of the theory do not enable the identification of potential obstacles for such transformation. Consequently, this article argues for incorporating a previously overlooked concept and an ideal of political emancipation into $\mathrm{t}$ participatory theorising. By incorporating political emancipation into its vocabulary, participatory theory can successfully address the disconnect from political practice and provide guidance in establishing improved political arrangements.

Keywords: emancipation; participatory democracy; conceptual analysis 
Participatory democracy, almost fifty years after its modern reappearance, remains disconnected from political practice. While the core claims of the theory emphasise the value of citizens' participation, empirical research repeatedly shows that large sections of democratic societies do not engage in decision-making processes (e.g. Lijphart, 1997; Solt, 2008). Furthermore, democratic researchers point to socio-economic status as one of the most reliable indicators of political engagement (Birch, 2009; Solt, 2008). Those who are better off are more likely to vote and, from the 1970s to the present day, those with a higher level of education are more likely to take part in other forms of democratic engagement (Lijphart, 1997; Stolle \& Hooghe, 2011). While the modern ideals of participatory democracy arose as a reaction against elitist versions of democracy (see Barber, 1984; Pateman, 1970), participatory practice relies on the political activism of the elites. Consequently, participatory democracy is 'often treated as a purely normative argument, concerned with ideals' instead of a project aiming to transform actual politics (Pateman, 2012, p. 10).

This article aims to target this disconnect and to propose a development at the level of participatory theory. Many participatory theorists argue that existing inequality leads to political apathy and a way to overcome this is to introduce a participatory society. Here, Barber explicitly claims that 'people are apathetic, because they are powerless, not powerless because they are apathetic' (Barber, 1984, p. 272). In such an interpretation, a participatory society is self-sustaining because 'the more the individuals participate the better able they become to do so' (Pateman, 1970, p. 43). According to participatory democrats, the introduction of a participatory society would result in the development of a political character among members of society and the transformation of 
current social relations into 'independence, a respect for others, a sense of dignity and a willingness to accept social responsibility' ("Port Huron Statement," 1962, p. 8). ${ }^{1}$ However, this paper argues that current participatory theory is not well equipped to identify existing, and potential, obstacles to reaching such a participatory, transformed society. More precisely, this article argues for complementing core participatory concepts and ideals with those of political emancipation. While political emancipation is often an aim of participatory institutions and projects, so far it has not been the core concept for this democratic approach (e.g. Baiocchi \& Ganuza, 2014; Fung \& Wright, 2001; Navarro, 2010). ${ }^{2}$ Participatory scholars, when writing about emancipation, consider it either a result of political participation or an implicit condition of participation (Dacombe, 2018, p. 25; Pitkin, 1981). This article argues for treating political emancipation explicitly as a necessary, but not sufficient, condition for achieving participatory society.

In its most general understanding, emancipation means breaking free from repression, control, slavery, restraint or domination (Susen, 2014). Where slavery, control, or domination exist, there is no room for participatory democracy. This is because democracy requires all members of the public to be able to take part in decisionmaking and to make political decisions freely. Drawing on the rich usage of the concept, in this article I define emancipation as having or gaining substantive opportunities in relation to the political sphere. According to this understanding, emancipation requires the absence of repression, control and restraint, as well as the presence of the relevant

\footnotetext{
${ }^{1}$ However, C. B. Macpherson, noting that transformed society is both a condition and a result of participatory politics, describes a 'vicious circle: we cannot achieve more democratic participation without a prior change in social inequality and in consciousness, but we cannot achieve the changes in social inequality and consciousness without prior increase in democratic participation' (Macpherson, 1977, p. 100).

${ }^{2}$ However, emancipation has been a key concept for critical and deliberative scholars. For example: Bohman (2005), Böker \& Elstub (2015), Dryzek (1990), Knops (2006), Kompridis (2006), Hammond (2018), Lettow (2015).
} 
infrastructure to enable the realisation of political opportunities. Some may argue that thanks to the universal provision of human rights, the end of colonialism and widespread democratisation, political emancipation is no longer needed. However, the fact that the same disempowered groups repeatedly do not engage in political processes, or are explicitly excluded from them, shows that political emancipation remains, in fact, a vital and urgent political project. ${ }^{3}$

This paper proceeds as follows: I start with a brief introduction of participatory democracy and its core concept of political participation. I then argue that in order for any concept to provide guidance for the transformation of a society, it needs to fulfil certain desiderata. In particular, it needs to: be applicable to the political sphere; act as a metric to identify what is wrong with current arrangements; and guide the implementation of better social and political arrangements. However, as I demonstrate, political participation fulfils these desiderata only partially. I then argue that the concept of political emancipation is better for diagnosing failings in existing political arrangements. This diagnostic function of political emancipation is especially useful for the transformative aims of participatory theory. The final section concludes.

\footnotetext{
3 There is a vast empirical literature showing the influence of socio-economic status and inequality on citizen participation. For a review of this literature see Parvin (2018).
} 


\section{Participatory Democracy and Political Participation}

The contemporary version of participatory democracy arose as a response to elitist and minimalist accounts of democracy (e.g. Sartori, 1987; Schumpeter, 1947). ${ }^{4}$ Contrary to those accounts, contemporary participatory theorists argue that the ideal of democracy should rely on creating various opportunities for citizens to influence political processes beyond periodic elections (Arnstein, 1969; Barber, 1984; Della Porta, 2018; Pateman, 1970). As Barber emphasises, the essence of participatory democracy is 'self-government by citizens rather than representative government' (Barber, 1984, p. 151). For Pateman (1970, 2012), participatory democracy is a political project aiming for the democratisation of contemporary societies. For the realisation of this project, both structural changes and the creation of a new, participatory society are necessary (Pateman, 2012, p. 10).

According to Rod Dacombe, the contemporary theory of participatory democracy relies on three pillars: direct participation of citizens in collective decision-making; popular control over the work of public officials and representatives; and the educational effects of civic participation on ordinary citizens (2018, pp. 26-33). In this article, I focus on two of these pillars, namely direct participation and its educational effect. Within the relevant literature, political participation usually refers to citizens' influence on, shared involvement in, or power in political decision-making. In particular, Sherry Arnstein (1969) famously conceptualises a ladder of political participation that refers to the extent of citizens' power to influence the result of the political process. The authors of the Port

\footnotetext{
${ }^{4}$ However, the theory's foundations can be traced to Alexis de Tocqueville, John Stuart Mill and JeanJacques Rousseau and, more recently, Mary Parker Follett (1998 [1918]) and G. D. H. Cole (1920).
} 
Huron Statement define participation as subjects having an 'individual share in those social decisions determining the quality and direction of his life' ("Port Huron Statement," 1962, p. 7). Carole Gould describes it as a 'direct and immediate involvement in the process of decision making by the individuals concerned' (Gould, 1988, p. 259). Finally, Pateman argues that political participation is 'a process where each individual member of a decision-making body has equal power to determine the outcome of decisions' (Pateman, 1970, p. 71).

For participatory theorists, participation in the political sphere should facilitate a wide range of positive individual and social changes (see Mansbridge, 1999). In particular, Cole argues that self-government in guilds can 'call out what is best in its members' and provides the 'maximum opportunity for personal and social selfexpression' (1920, p. 12). The Port Huron authors argued that political participation would encourage people to get 'out of isolation and into community' ("Port Huron Statement," 1962, p. 8). Pateman, drawing on the work of G. D. H. Cole, argues that political participation facilitates political education and socialisation which in turn lead to the increased political efficiency of the members of society (Cole, 1920; Pateman, 1970). Following this account, political participation is a tool of civic education that enables citizens to gain knowledge, democratic skills and practice, and, as a result, facilitates their empowerment (Pateman, 1970). Finally, for Barber, politics in the participatory mode enables the 'transforming [of] dependent private individuals into free citizens' (1984, p. 151). In the next section, I will investigate if political participation is enough to bring about such positive change. In particular, I will focus on the concept of political participation as the core theoretical tool for the participatory theorist. 


\section{Why Political Participation is Not Enough}

In order for any concept to act as a helpful tool for the transformative aims of participatory democracy, it needs to perform specific functions. First of all, such a concept needs to focus on the political sphere as opposed to spheres that are not political. Furthermore, it needs to enable the identification of barriers and obstacles that hinder social transformation. Finally, it needs to describe what a desirable society or polity looks like. It is possible to describe these functions as three desiderata. I will now describe each of them and explain their function in participatory democracy:

(a) The concept in question is political - the concept is applicable to 'the political sphere'.

This desideratum refers to the domain of applicability of the concept (see List \& Valentini, 2016, p. 531). Its importance derives from the fact that democracy (including participatory democracy) is an idea that belongs to 'the political'. 'The political' is a sphere of social life and can be understood in a broad or a narrow way, and the definition of democracy depends on the breadth, or narrowness, of this understanding. For example, it is possible to define 'the political' in a narrow way according to the public vs. private divide. This distinction, roughly, refers to the public sphere as that which is regulated by government, thus separate to the private sphere, which is regulated by self-control (Mill, 2011 [1859]). Following this division, 'the political' describes the public sphere but not the private one. However, participatory democrats explicitly argue for a broader 
understanding of what constitutes 'the political'. In the participatory approach, private spheres, such as a workplace, a neighbourhood, or a household, are political and should therefore be subjected to democratic decision-making and engagement (Barber, 1984; Pateman, 1970). Pateman (1970) makes a case for the workplace as a site of participatory democracy, while Gould (1988, p. 260) focuses on institutions of local governance. As a result, a concept that is suitable for the aims of the participatory project should correspond to this broader understanding of 'the political'. A concept in which the sphere of applicability is too narrow will not identify a lack of participation in some of the spheres as problematic; for example, the narrow understanding of 'the political' does not allow for an assessment of whether or not decision-making in private enterprise is democratic. However, inequalities of participation in workplace decision-making are, usually, problematic for participatory democrats (see Pateman, 1970).

(b) The concept in question enables a diagnosis - it provides a metric to identify what is wrong with existing arrangements.

This desideratum relates to the evaluative role of concepts in political theory (see List \& Valentini, 2016). It arises as a consequence of thinking about a given concept as a metric to help identify barriers and obstacles to reaching participatory ideals and criticising nondemocratic or oppressive circumstances. A concept suitable for the aims of participatory democracy should enable the identification of obstacles or barriers to political participation and the realisation of positive individual and social transformations. Hence a concept that is fit to meet the aims of participatory theory should enable the identification 
of factors that could potentially hinder the educational effects of political participation and the transformation of social relations.

(c) The concept in question is practical - it can guide the establishment of desirable institutional and social arrangements.

The last desideratum arises out of the practical implications of the participatory theory. The participatory theorist aims not only to analyse current circumstances, but also to actively shape a better participatory society. Pateman (2012, p. 10) emphasises that participatory democracy offers an argument about 'changes that will make our own social and political life more democratic, that will provide opportunities for individuals to participate in decision-making in their everyday lives as well as in the wider political system'. Barber explicitly proposes a twelve-point program for transforming existing politics into the participatory mode (1984, p. 307). Hence, core concepts applied by participatory theory should have a practical dimension and ought to enable the identification of institutions and arrangements that can facilitate participatory aims.

These three desiderata are jointly necessary for a concept to serve effectively as a tool for realising the transformative aims of a participatory democracy. However, the concept of 'political participation' fulfils these desiderata only partially. Political participation, understood as a citizen's power to influence the shape of the political system or society, applies to the political sphere beyond the formal institutions of the state. It is possible to identify this power in a variety of decision-making systems, including those in which participatory democrats are interested: namely workplace; 
family; and neighbourhood. However, the concept of political participation enables only a partial diagnosis of the existing hindrances to the individual and social transformations envisioned by participatory democrats. For example, even if political participation is understood as citizens' power to shape the political system, they may be constrained by psychological barriers, such as fear, or shame, that render them unable to benefit from this power. Furthermore, the concept of political participation is only partially practicable. The realisation of participatory aims requires citizens' involvement in and influence on the decision-making process, but also requires suitable institutional arrangements to facilitate participation. Such arrangements need to ensure that political participation is consequential and results in political change.

Partial realisation of the diagnostic and practical functions means that the concept of political participation alone is not the best tool for the participatory theorist. In the following sections, I argue for the supplementation of participatory theory with a new idea and concept, namely that of political emancipation. Political emancipation is often implicitly present in participatory theory (e.g. Pitkin, 1981), but, until now, it has not been explicitly employed in this body of literature. I start with an analysis of what political emancipation can mean.

\section{Three Dimensions of Political Emancipation}

The concept of emancipation, etymologically, refers to the breaking free from a set of constraints. The term's original meaning comes from Roman law, where it meant a release from legal bondage (Lettow, 2015), and in particular to being freed from 
ownership by another person (Coole, 2015). According to historian Reinhart Koselleck, in modern times the concept has shifted from its legal origins, and has become political (Koselleck \& Grass, 1975). As such, emancipation no longer entails freeing somebody else, but rather, reflects a self-transformation (Lettow, 2015, p. 503). Similarly, Diana Coole argues that, since the Enlightenment, emancipation can be understood as 'active criticism' that recognises 'institutionalised power's capacity to seduce subjects into voluntary obedience even when they enjoy formal liberty' (Coole, 2015, p. 532). In this understanding, emancipation is an active, psychological process.

In this section, I investigate how emancipation is currently understood by political theorists. More precisely, I engage in conceptual analysis and identify several ideal aspects which refer to different elements of the concept of emancipation. Hence, I elaborate on emancipation as a process and a state of affairs, emancipation in its positive and negative meaning as well as its internal and external form.

Let's start by distinguishing between emancipation as a process and emancipation as a state of affairs. The division between a state of affairs and a process reflects a division between circumstances $z$ and the process aiming at arriving at circumstances $z .^{5}$ While emancipation in most frequent usage refers to the process, its Latin suffix -ion reflects both the process and the state of affairs (Stevenson, 2010). More analytically, emancipation as a state of affairs reflects a situation in which an agent or a group is emancipated. For example, following the original meaning of emancipation applied in Roman law, an emancipated agent is no longer the property of another person. In this example, the concept of emancipation is used to describe a state of affairs in which the

\footnotetext{
${ }^{5}$ Here, $z$ can be further specified .
} 
agent is not constrained by legal bondage. In contrast, in Coole's (2015) interpretation, emancipation reflects a process.

Emancipation understood both as a state of affairs and as a process is equally relevant to democratic theory. A polity can be emancipated when we consider emancipation as a state of affairs. Alternatively, a group which is in the process of securing or acquiring, for example, individual rights or opportunities is in the process of becoming emancipated. This distinction is helpful as it can refer to political and social arrangements in a polity and to a process of democratisation, respectively. A polity is emancipatory if it features specific emancipatory characteristics. For example, one can argue that it is a polity that secures freedom from some form of coercion for all its citizens. This dimension is essential for the aims of participatory democracy since it enables one to analyse existing polities and societies from the perspective of participatory aims. Consequently, a polity or a society is in the process of emancipatory democratisation if it is in the process of gaining some emancipatory characteristics. For example, emancipation could occur through a democratic transition, as in the case of a previously non-democratic country that is becoming a democracy. However, such emancipation is also appropriate for describing dynamic communities where the composition of members is changing. Here, emancipation can refer to new members who, by joining the polity, gain certain rights or opportunities. These rights and opportunities, in turn, enable them to participate fully in the political life of the polity. Emancipation as a process is similarly essential for the aims of participatory democracy since it enables the identification of processes that lead to the establishment of a democratic society. 
Furthermore, it is possible to think of emancipation as referring to two dimensions. The first dimension addresses the question of whether emancipation is employed as a negative or a positive notion. A negative aspect of emancipation refers to the removal or absence of a particular phenomenon or condition(s). As a positive aspect, emancipation reflects the presence or introduction of some kind(s) of condition(s). ${ }^{6}$ The internal vs. external dimension describes the character of the phenomena or conditions to which emancipation refers. Emancipation can refer to conditions which are external to the agent of emancipation or conditions which are within an agent's capacity. Here, an external aspect of emancipation can refer to socio-economic conditions or features of the decision-making process of which an agent is a part. An internal aspect of emancipation can refer to the internal features of the agent, such as an agent's abilities or desires. ${ }^{7}$ These three dimensions create a two $x$ two $x$ two matrix of different aspects of emancipation. It is possible to see the roots of these two dimensions in the classical analyses of freedom by, separately, Erich Fromm (1984 [1942]) and Isaiah Berlin (1969). ${ }^{8}$ These aspects, shown in Table 1 below, are a result of the conceptual analysis, which means that each of them needs to be further filled by a relevant definition of emancipation. How emancipation is used within the existing literature can, and usually does, cover one or more of these aspects at once. I now discuss each aspect of

\footnotetext{
${ }^{6}$ These two notions of emancipation are conceptually distinct. However, in the literature, they are often elided. To illustrate, emancipation can be used to describe a process of the removal of some circumstances and the introduction of new ones at the same time.

${ }^{7}$ Again, these two dimensions are conceptually distinct and yet they can often be elided in the literature. One can also note that this distinction emphasises the location of the feature (external vs. internal) but not its character (e.g. arbitrary or not). Because of this, the character of the feature should be spelled out by an appropriate substantive definition of emancipation.

8 Positive freedom in Berlin's understanding would be a positive internal concept according to my typology, while negative freedom would be a negative external notion.
} 
emancipation and analyse its suitability for assessing real-life arrangements and for describing political forms of emancipation.

\begin{tabular}{c||c|c||}
\multicolumn{1}{||c|}{\begin{tabular}{c}
\multicolumn{2}{c|}{ External or internal? } \\
1. Negative external \\
Process/state of affairs
\end{tabular}} & $\begin{array}{c}\text { 2. Negative internal } \\
\text { Negative } \\
\text { or positive? }\end{array}$ & Process/state of affairs \\
\cline { 2 - 3 } & $\begin{array}{c}\text { 3. Positive external } \\
\text { Process/state of affairs }\end{array}$ & 4. Positive internal \\
& & Process/state of affairs \\
\cline { 2 - 3 } & &
\end{tabular}

Table 1: Different aspects of emancipation

The first aspect of emancipation, negative external, emphasises $z$ where:

$z=$ the removal or the absence of relevant agency-restricting features external to the agent.

Definitions of emancipation as a negative external concept are widely used in current democratic literature, such as an understanding of emancipation as the removal or absence of certain social constraints. In political environments, such conditions could refer, for example, to the absence of an oligarchic group or a dictator who makes all the decisions. Coole argues that such negative external meaning of emancipation reflects its ancient origins referring to the release from legal bonds. Furthermore, in her interpretation, this understanding was adopted by first-wave feminists, who drew 
analogies between the situation of women and slavery (Coole, 2015). Emancipation as a negative external process is used in the current critical theory literature which often defines emancipation as breaking free from circumstances of domination (Bohman, 2005; Dryzek, 1990, pp. 2-22; Hammond, 2018; Held, 1980, p. 250; Kompridis, 2006, p. 20) or from 'those forms of social life and of the juridical, political, and cultural orders which have become a straitjacket' for individuals (Horkheimer, 1982, p. 230). For critical theorists, however, a negative aspect of emancipation usually needs to be complemented with an internal aspect, which I will discuss further.

Now, let's consider if this aspect is suitable for the aims of participatory democracy. It certainly is, since a negative external aspect of emancipation emphasises features of decision-making, or elements of the political setting, which need to be removed to make a polity participatory. This aspect of the concept of emancipation can also fulfil most of the aforementioned desiderata. It is suitable for the description of the political sphere, in both its narrow and broad understandings, since it emphasises the characteristics of the socio-political circumstances. It enables the diagnosis of existing circumstances. For example, from the perspective of participatory democracy, a society in which slavery exists cannot be democratic. However, this aspect of the concept of emancipation does not fulfil the practical desideratum. While it identifies what needs to be absent from society or a polity in order to call it participatory and democratic, it does not identify what needs to be present. More precisely, a society which is characterised by the lack of any formal tools and institutions for citizens' engagement might then also be described as emancipatory and democratic, provided there are at least no external formal constraints to participation in that society. As such, this aspect of the concept of 
emancipation can be political and diagnostic but does not guide the establishment of desirable institutional and social arrangements. From the perspective of participatory democracy, at least a minimal understanding of external positive emancipation, such as the presence of consequential decision-making, is necessary, but not sufficient, for designing democratic polity.

The second aspect of emancipation, negative internal, highlights $z$ where:

$z=$ the removal or the absence of relevant agency-restricting features of the agent himor herself.

This aspect of emancipation refers to the absence or removal of some characteristics of the agent of emancipation. Here, it is possible to imagine that a person who is emancipated is freeing oneself, or is free, from some limitations. For example, it is possible for members of an authoritarian society to free themselves from the fear of the authorities and punishment despite the lack of change in the political system. This aspect of emancipation could also be suitable for the description of democracy, especially if one defines the political sphere as the participatory democrats do. For example, this aspect of emancipation may mean a removal of the absence of fear to make a decision. It may be impossible to have democracy if all members of the society are too afraid to make up their minds and to choose the political option which is, in their opinion, the best one. This aspect of the concept of emancipation enables further a proper diagnosis of potential barriers to successful implementation of participatory democracy. If the internal barriers or obstacles exist, like fear or shame to participate in political life, participatory 
democracy does not hold. Furthermore, this aspect of emancipation has a practical dimension by identifying what internal features of members of the participatory society cannot be present.

The third aspect of emancipation, positive and external, stresses $z$ where:

$z=$ the presence or the acquisition of relevant agency-conducive features external to an agent.

This aspect of emancipation refers to the presence or introduction of some features of the decision-making process, or socio-economic conditions, in which the agent is situated. It can refer to, for example, the presence or acquisition of rights, status or opportunities. Positive and external emancipation, for example, can describe the situation of women at the beginning of the twentieth century who gained voting rights. This aspect of emancipation is also suitable for the aims of participatory democracy. It fulfils the practical desideratum since it emphasises the elements of decision-making or the political setting that need to be present to describe a society as democratic. For example, a society can only be called democratic if there are the relevant institutions in place that enable active citizen participation. This aspect of the concept of emancipation is especially apt for the diagnostic function of political concepts. Here, a society that does not have institutions that enable the political participation of its citizens, despite the lack of some external constraints, cannot be called democratic. The positive and external aspect of emancipation is also suitable for describing the political sphere, since it points out characteristics of a society or polity that need to be present in democratic arrangements. 
Finally, the fourth aspect considers emancipation as $z$ where:

$z=$ the presence or the acquisition of relevant agency-conducive features of the agent him-or herself.

According to this aspect of emancipation, one becomes emancipated when one gains new internal capabilities. This aspect of emancipation is applied, for example, by Diana Taylor. For Taylor, emancipation means an ability to engage with the conditions of power critically and to modify, negotiate or reverse these power relations (2009). Positive and external emancipation is also employed by Joan Scott who argues that emancipation 'is not a matter of being free of prior impediments, but of understanding oneself' (2012, p. 152). Similarly, Coole, in her interpretation of Kant and Foucault, considers emancipation as a critical process in which subjects free themselves from the psychological influence of authority (Coole, 2015). Other examples could include gaining new capabilities, such as courage and skills for public speaking. This aspect of emancipation can-again-be used to describe the emancipation of women at the beginning of the twentieth century when this group, thanks to gaining voting rights, could, en masse, develop new skills and knowledge. This aspect of emancipation is also crucial for participatory democracy. Here, participatory democrats argue that a process of participation in political life creates externalities, also in terms of personal skills or knowledge (Dacombe, 2018, p. 10). Here the positive internal aspect of emancipation can be useful in describing such externalities, and as such it fulfils the practical function, describing what sort of externalities a good participatory society should achieve. This 
aspect also fulfils the diagnostic function. Here, one can argue that in a society without such positive externalities, members are not emancipated. This is because the lack of such positive externalities signifies the presence of certain obstacles to gaining skills or knowledge. Such obstacles can relate to structural constraints, or the presence of social stigma, or fear. However, one could argue that this aspect of emancipation goes too far into the personal sphere to be suitable for the description of the political sphere. Here participatory democrats would certainly include at least some internal characteristics of the citizens as both political and vital for democracy. In a very minimal version, such internal characteristics can refer to an ability to make up one's mind.

After analysing different aspects of the concept of emancipation, I can analyse which aspect is suitable for the aims of participatory democracy. Just to remind, I am looking for an aspect or aspects which are political, practical and diagnostic. By providing examples of these different aspects of the concept of emancipation and their suitability for describing democracy, I have shown that all of these aspects are political and suitable for the description of 'the political sphere'. Here, all the aspects of the concept are appropriate: the positive and negative, internal and external aspects are essential for the individual to be able to influence 'the political'. Now, one can argue that similarly, all the aspects of the concept of emancipation are jointly suitable for diagnostic and practical aims. In order to describe and guide real-life institutions, the internal and external, positive and negative aspects of emancipation are, again, essential. This is because the external aspect of emancipation shows what needs to be present or absent in a particular society. The internal aspect, on the other hand, describes what cannot be imposed on or taken from the members of the polity. 
Up to this point, I have discussed several aspects of political emancipation. Drawing on this analysis, I can now define political emancipation as having or gaining substantive opportunities within the political sphere. This notion of emancipation, which is positive and negative, internal and external can also refer to a process or a state of affairs. In this case, in order to be substantive, opportunities need to be in line with the emancipated agent's motivations and desires. Emancipation understood as gaining or having substantive opportunities includes the aims and desires of the emancipated person or group. Additionally, for opportunities to be genuinely substantive, they need to be consequential. This understanding of emancipation refers to both the process and a state of affairs. It can refer to having substantive opportunities within the political sphere, widening the scope of one's existing abilities or gaining new ones so as to influence the political sphere. Consequential substantive opportunities require the presence of certain characteristics of the socio-political arrangements that enable citizens to influence the sphere of 'the political' once they choose to do so. For example, the relevant institutions and rules of law are necessary. However, the absence of obstacles to such influence, like domination or slavery, is also required. Finally, emancipation understood as gaining or having substantive opportunities within the political sphere relies on specific internal characteristics. For example, a citizen needs to reflect on their own motivations and objectives in order for the opportunities to count as substantive.

After analysing the multifaceted nature of political emancipation and defining it as gaining or having substantive opportunities, in the next section I investigate whether political emancipation can be a corrective to the limitations of current participatory theory. 


\section{Political Emancipation and Inequalities of Participation}

In a previous section, I demonstrated that the concept of political participation does not fulfil all the desiderata necessary for the practical aims of participatory theory. In particular, I have argued that the concept of political participation does not enable the identification of obstacles to the realisation of participatory aims. As an example of such potential obstacles I have mentioned feelings of fear or shame. The presence of those feelings can hinder both participation and the positive effects of political engagement. Furthermore, I have argued that the concept of political participation is not entirely practical either. Here, I have illustrated this point by arguing that for political participation to take place, the relevant institutional infrastructure needs to exist in order to enable that activity and make participation consequential. As such, I have argued, the concept of political participation is a limited conceptual tool for providing guidance for the establishment of a better participatory society. These limitations of the concept of political participation can be named alongside the dimensions of conceptual analysis introduced above. In particular, the concept of political participation lacks an internal negative aspect and is not able to rule out the presence of fear or shame as problematic. In addition, the concept of political participation lacks an external positive aspect since it does not prescribe precisely what sort of institutional arrangements need to be present in a participatory society. ${ }^{9}$

The concept of political emancipation is a better diagnostic and practical tool. As I have demonstrated, it is a multifaceted, nuanced concept that is positive and negative,

\footnotetext{
9 This applies, however, when participation is understood as involvement in decision-making, and less so when it is defined as power.
} 
internal and external. Political emancipation understood as having or gaining substantive opportunities within or in relation to the political sphere fulfils three functions that are necessary for the practical aims of participatory theory. It is political and can correspond to both a narrow and a broad understanding of the 'political sphere'.

Furthermore, this understanding of the concept also enables the identification of conditions that hinder the realisation of participatory aims. If there are any internal or external constraints undermining a person's participation, for example feelings of shame or the threat of punishment, a concept of political emancipation enables the identification of these conditions as problematic. In other words, if a person feels shame or is afraid of punishment, the person is not emancipated. Even if this person had the right to participate, shame or fear of punishment would hinder the occurrence of positive individual and societal effects.

Similarly, the concept of political emancipation is practical. It enables the identification of conditions that need to be present to create a participatory society. In this sense, members of society cannot be emancipated if there is no infrastructure for their opportunities to be consequential. Likewise, they cannot benefit from participation if such infrastructure does not exist. In this sense, political emancipation appears as a necessary, but not sufficient, condition for achieving a participatory society. Table 2 (below) lists possible functions of participatory theory with and without incorporating the concept, and the ideal, of political emancipation. 


\section{Participatory theory that relies primarily on the concept of political participation:}

Does it focus on a sphere or spheres that is/ are political?
Applicable to the broad understanding of the 'political sphere'
Participatory theory that incorporates the concept and the ideal of political emancipation:

Applicable to the broad understanding of the 'political sphere'.
Does it identify obstacles to political participation and those that hinder achieving participatory society?
Does not flag up internal and psychological obstacles hindering political participation as problematic.
Can point out external and internal conditions as barriers to effective participation and to participatory society.
Is it practical and does it identify institutions and arrangements that facilitate participatory aims?
Does not always identify institutional arrangements that facilitate social change.
Emphasises the need for the relevant institutional and social arrangements that enable participation and achievement of participatory aims.

Table 2: Participatory Theory: With and Without Political Emancipation

While the concept of political emancipation is a helpful tool for describing necessary logical conditions for participatory society, it can also help to address existing inequalities in political participation. For example, one of the consequences of inequalities in political participation is that members of disempowered groups are outnumbered by those who are better off and who have higher socio-economic status (Lijphart, 1997; Stolle \& Hooghe, 2011). Here, thinking about emancipation as a condition of political participation can enable the political theorist to respond to those inequalities. For example, participatory democrats can argue that members of disempowered groups are not participating due to structural constraints and, for 
democracy to hold, their emancipation is necessary. Furthermore, participatory theorists may argue that the better off and those with higher socio-economic status currently dominate politics, which makes modern polities undemocratic. As such, the concept of political emancipation can help to address the disconnect between participatory theory and practice.

\section{Conclusion}

The aim of this article has been to address the disconnect between participatory theory and political practice. While participatory theory emphasises the individual and social effects of political participation, the key concept within this theory is a somewhat limited conceptual tool for establishing the conditions for such changes. Working at the theoretical level, this article has argued for the need to complement participatory theory with the concept, and the ideal, of political emancipation, understood as having or gaining substantive opportunities within or in relation to the political sphere. I have argued that such a concept of emancipation is a useful conceptual tool that enables us to identify the obstacles and the changes necessary for realising the positive and transformative effects of participation. 
References:

Arnstein, S. R. (1969). A Ladder Of Citizen Participation. Journal of the American Institute of Planners, 35(4), 216-224. doi: 10.1080/01944366908977225

Baiocchi, G., \& Ganuza, E. (2014). Participatory Budgeting as if Emancipation Mattered. Politics \& Society, 42(1), 29-50. doi: 10.1177/0032329213512978

Barber, B. R. (1984). Strong democracy: participatory politics for a new age. Berkeley, CA: University of California Press.

Berlin, I. (1969). Two Concepts of Liberty. In I. Berlin (Ed.), Four Essays on Liberty. London: Oxford University Press.

Birch, S. (2009). Full participation : a comparative study of compulsory voting. Manchester, UK: Manchester University Press.

Bohman, J. (2005). Critical Theory. In E. N. Zalta (Ed.), The Stanford Encyclopedia of Philosophy (Fall 2016 ed.).

Böker, M., \& Elstub, S. (2015). The Possibility of Critical Mini-Publics: Realpolitik and Normative Cycles in Democratic Theory. Representation, 51(1), 125-144. doi: $10.1080 / 00344893.2015 .1026205$

Cole, G. D. H. (1920). Guild socialism restated. London: L. Parsons.

Coole, D. (2015). Emancipation as a Three-Dimensional Process for the Twenty-First Century. Hypatia, 30(3), 530-546.

Dacombe, R. (2018). Beyond abstract democracy: Rethinking civic participation in theory and practice Basingstoke: Palgrave Macmillan UK. 
Della Porta, D. (2018). For participatory democracy: some notes. European Political Science, 1-14. doi: 10.1057/s41304-018-0198-z

Dryzek, J. S. (1990). Discursive democracy: politics, policy, and science. Cambridge: Cambridge University Press.

Follett, M. P. (1998 [1918]). The new state: group organization the solution of popular government. University Park, Penn: The Pennsylvania State University Press.

Fromm, E. (1984 [1942]). The Fear of Freedom. London: Ark Paperbacks.

Fung, A., \& Wright, E. O. (2001). Deepening Democracy: Innovations in Empowered Participatory Governance. London: Verso.

Gould, C. C. (1988). Rethinking democracy: freedom and social cooperation in politics, economy and society. Cambridge: Cambridge : Cambridge University Press.

Hammond, M. (2018). Deliberative democracy as a critical theory. Critical Review of International Social and Political Philosophy, 1-22. doi: $10.1080 / 13698230.2018 .1438333$

Held, D. (1980). Introduction to critical theory: Horkheimer to Habermas. London: Hutchinson.

Horkheimer, M. (1982). Critical theory: selected essays. New York: Continuum.

Knops, A. (2006). Delivering Deliberation's Emancipatory Potential. Political Theory, 34(5), 594-623. doi: 10.1177/0090591706290780

Kompridis, N. (2006). Critique and disclosure: critical theory between past and future. Cambridge, MA: MIT Press. 
Koselleck, R., \& Grass, K. M. (1975). Emanzipation. In O. Brunner, W. Conze \& R. Koselleck (Eds.), Geschichtliche grundbegriffe: Historisches lexikon zur politisch-sozialen sprache in Deutschland (Vol. 2). Stuttgart: Klett-Cotta.

Lettow, S. (2015). Editor's Introduction-Emancipation: Rethinking Subjectivity, Power, and Change. Hypatia, 30(3), 501-512. doi: 10.1111/hypa.12163

Lijphart, A. (1997). Unequal Participation: Democracy's Unresolved Dilemma Presidential Address, American Political Science Association, 1996. American Political Science Review, 91(1), 1-14. doi: 10.2307/2952255

List, C., \& Valentini, L. (2016). The Methodology of Political Theory. In H. Cappelen, T. S. Szabó Gendler \& J. Hawthorne (Eds.), The Oxford Handbook of Philosophical Methodology. Oxford: Oxford University Press.

Macpherson, C. B. (1977). The life and times of liberal democracy. Oxford: Oxford University Press.

Mansbridge, J. (1999). On the Idea That Participation Makes Better Citizens. In S. L. Elkin \& K. E. Sołtan (Eds.), Citizen competence and democratic institutions (pp. 291-325). University Park, PA: Pennsylvania State University Press.

Mill, J. S. (2011 [1859]). On Liberty. Luton: Andrews UK Limited.

Navarro, Z. (2010). Porto Alegre From Municipal Innovations to the Culturally Embedded Micro-Politics of (Un)Emancipated Citizens: The Case of Rubbish Recyclers In J. Pearce (Ed.), Participation and Democracy in the Twenty-First Century City. Basingstoke: Hampshire.

Parvin, P. (2018). Democracy Without Participation: A New Politics for a Disengaged Era. Res Publica, 24(1), 31-52. doi: 10.1007/s11158-017-9382-1 
Pateman, C. (1970). Participation and democratic theory. London: Cambridge University Press.

Pateman, C. (2012). Participatory Democracy Revisited. Perspectives on Politics, 10(1), 7-19. doi: 10.1017/S1537592711004877

Pitkin, H. F. (1981). JUSTICE: On Relating Private and Public. Political Theory, 9(3), 327-352. doi: 10.1177/009059178100900304

Port Huron Statement. (1962). Retrieved 21/08/2019, from http://www.progressivefox.com/misc_documents/PortHuronStatement.pdf

Sartori, G. (1987). The theory of democracy revisited. Parts 1\&2. Chatham, N.J.: Chatham House Publishers.

Schumpeter, J. (1947). Capitalism, Socialism and Democracy. New York: Harper and Brothers.

Scott, J. W. (2012). The Vexed Relationship of Emancipation and Equality. History of the Present, 2(2), 148-168. doi: 10.5406/historypresent.2.2.0148

Solt, F. (2008). Economic Inequality and Democratic Political Engagement. American Journal of Political Science, 52(1), 48-60. doi: 10.1111/j.15405907.2007.00298.x

Stevenson, A. e. (Ed.) (2010) Oxford Reference. Oxford: Oxford University Press.

Stolle, D., \& Hooghe, M. (2011). Shifting Inequalities. European Societies, 13(1), 119142. doi: $10.1080 / 14616696.2010 .523476$

Susen, S. (2014). Emancipation. In M. T. Gibbons (Ed.), The Encyclopedia of Political Thought (pp. 1024-1038). Chichester: Wiley Blackwell

Taylor, D. (2009). Normativity and Normalization. Foucault Studies, 7, 45-63. 